Primljen / Received: 23.11.2016. Ispravljen / Corrected: 10.4.2017.

Prihvaćen / Accepted: 22.5.2017.

Dostupno online / Available online: 10.12.2017.

\section{Durability characteristics of copper slag concrete with fly ash}

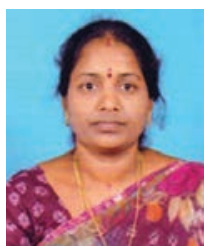

Assist.Prof. Sumathy Raju, PhD. CE

Alagappa Chettiar College of Engineering and Technology

Karaikudi, Tamil Nadu, Indija

sr.sumathy5@gmail.com

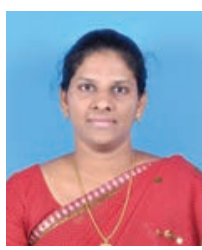

Assist.Prof. Brindha Dharmar, PhD. CE

Thiagarajar College of Engineering

Madurai, Tamil Nadu, Indija

dbrindha@yahoo.co.in

\section{Sumathy Raju, Brindha Dharmar \\ Durability characteristics of copper slag concrete with fly ash}

The durability of the combination of Fly Ash (FA) and Copper Slag (CS) in concrete is studied in the paper. Experimental study was conducted to determine durability properties such as saturated water absorption, porosity, coefficient of water absorption, sorptivity, rapid chloride ion penetration test, and Alkalinity (pH) test. The microstructure of concrete was tested and quantitative analysis was carried out at the age of 90 days by the scanning electron microscope and energy dispersive $X$-ray. The results show that concrete properties are improved by the combined use of FA and CS.

\author{
Key words: \\ copper slag concrete, flay ash, water absorption, porosity, chloride ion penetration
}

Stručni rad

Sumathy Raju, Brindha Dharmar

\section{Karakteristike trajnosti betona s bakrenom zgurom i s dodatkom letećeg pepela}

U radu se razmatra trajnost kombinacije letećeg pepela (FA) i bakrene zgure (CS) u betonu. Provedeno je eksperimentalno istraživanje o pokazateljima trajnosti kao što su upijanje vode do zasićenja, poroznost, koeficijent upijanja vode, sorptivnost, brzi pokus prodiranja kloridovih iona te pokus alkalnosti (pH). Ispitana je i mikrostruktura betona te je obavljena kvantitativna analiza nakon 90 dana pomoću pretražnog elektronskog mikroskopa i energijski razlučujuće rendgenske spektrometrije. Dobiveni rezultati pokazuju da se primjenom kombinacije FA i CS poboljšavaju svojstva betona.

Ključne riječi:

beton s bakrenom zgurom, leteći pepeo, upijanje vode, poroznost, prodiranje kloridovih iona

Fachbericht

Sumathy Raju, Brindha Dharmar

\section{Merkmale der Beständigkeit von Beton mit Kupferschlacke und Flugasche}

In der Arbeit wird die Beständigkeit der Kombination von Flugasche (FA) und Kupferschlacke (CS) im Beton untersucht. Es wurde eine experimentelle Untersuchung der Parameter wie Wasseraufnahme bis zur Sättigung, Porosität, Koeffizient der Wasseraufnahme, Sorptivität, Schnelltest der Eindringung von Chloridionen und ein Alkalinitätstest (pH) durchgeführt. Es wurde die Mikrostruktur des Betons geprüft und eine quantitative Auswertung nach 90 Tagen anhand eines Elektronenmikroskops und einer energieauflösenden Röntgenspektrometrie durchgeführt.

Schlüsselwörter:

Beton mit Kupferschlacke, Flugasche, Wasseraufnahme, Porosität, Eindringung von Chloridionen 


\section{Introduction}

Every concrete structure should continue to perform its intended functions to the required strength and serviceability levels during the specified or traditionally expected service life. Moreover, concrete used in such structures must be able to withstand the processes of deterioration to which it is expected to be exposed. Such concrete is said to be durable [1]. Concrete has been the most significant building material for many generations. Concrete structures are built in highly polluted urban and industrial areas, aggressive marine environments, harmful subsoil water, coastal areas, and in many other hostile environments. Large sums of money are being spent on concrete repair and maintenance and, as a result, concrete must be able to withstand various deterioration processes.

When excess water in concrete evaporates, it leaves voids inside the concrete element by creating capillaries that are directly related to the concrete porosity and permeability. Hydration products consist of C-S-H gel, ettringite crystals, and monosulphate, and of related gel pores, capillary pores, and entrapped and entrained air voids. These are the factors that cause porosity of concrete. The volume of moisture that may pass through concrete depends on its permeability. The permeability of cement paste also varies with the age of concrete or with the degree of hydration. Almost impervious concrete can be obtained by proper selection of ingredients, mix proportioning, and following good construction practices [2]. Although compressive strength is to a great extent a measure of durability, it is not entirely true that strong aggregate is always needed for a durable concrete [3]. So, the durability of concrete depends on environmental conditions and also on the movement of water and gas through concrete. Good particle packing density of concrete prevents solely the penetration of water and other chemicals.

The durability of concrete is mostly affected by three factors: water that carries pure or aggressive ions, carbon dioxide, and oxygen. They can move through concrete in different ways, but all transports depend primarily on the structure of the hydrated cement paste. The movement of various fluids through concrete takes place not only by flow through the porous system, but also by diffusion and sorption. Hence, the main concern is really the penetrability of concrete [4].

The sorptivity or capillary suction is the transport of liquids in porous solid due to surface tension, acting on capillaries, viscosity, density, surface tension of the liquid, and pore structure [5]. Concrete is a strong and tough material but it is porous and so it interacts with the exposed environment. The sorptivity of concrete is a quantity that measures the unsaturated flow of fluids in concrete [6].

The application of flay ash (FA) in concrete mixture improves durability properties because it ensures lower permeability and an improved microstructure of concrete [3]. As a result, FA concrete not only improves properties of concrete, but it also helps in preventing environmental pollution. Various studies have been made with regard to the use of FA for cement, and copper slag as a substitute for fine aggregate. Concrete with $25 \%$ of FA content as a cement replacement material showed lowest value of saturated water absorption, sorptivity, and chloride diffusion compared to values obtained at control concrete mixes. The porosity increases with an increase in FA replacement level and decreases with an increase in its fineness. In previous studies, it is reported that the inclusion of FA reduces the sorptivity and chloride ion permeation significantly at 28 days, and that these values reduce even further at 6 months. [7-9].

Concrete with $40 \%$ of copper slag (CS) as sand substitute can achieve higher strength compared to the control concrete [10, 11]. The durability characteristics such as water absorption and permeability decrease continuously with an increase in copper slag content [12]. However, not many durability studies have been made with regard to FA and copper slag (CS) incorporated in concrete. Thus, this experimental study focuses on transport properties of concrete containing FA and CS. Furthermore, microstructural studies and quantitative analysis are conducted by SEM (Scanning Electron Microscope) and EDAX (Energy Dispersive X-ray analysis), respectively. Preliminary compressive strength testing is conducted on cubes at $7,28,56$, and 90 days. The concrete strength increases in proportion with an increase in curing period. At 90 days, the strength varies from $43.22 \mathrm{~N} / \mathrm{mm}^{2}$ to $59.11 \mathrm{~N} / \mathrm{mm}^{2}$. In addition, CS used as replacement for fine aggregate in the proportion of up to $100 \%$ behaves better when compared to control concrete.

\section{Experimental study}

\subsection{Materials}

The Chettinad Ordinary Portland Cement (OPC), i.e. a 43 grade cement compliant with IS8112 (part1), 2013 [13], was used in the experimental investigation. Its basic properties were evaluated, as shown in Table 1. The low calcium fly ash (class F) obtained from Thermal Power Plant, Salem (Tamil Nadu), India, compliant with IS3812 (part1), 2003 [14], was used. The specific gravity of fly ash was 2.18 . The fine aggregate was first sieved through $4.75 \mathrm{~mm}$ sieve to remove the particles greater than $4.75 \mathrm{~mm}$. Crushed blue granite stone of maximum size 20 $\mathrm{mm}$ was used as coarse aggregate. The copper slag used in this paper was obtained from Sterlite Industries India Limited (SIIL), Tuticorin and Tamil Nadu.

Table 1. Properties of cement (OPC 43 grade) and mortar

\begin{tabular}{|c|c|c|}
\hline \multirow{4}{*}{ 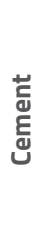 } & Specific gravity & 3,05 \\
\hline & Standard consistency [\%] & 36 \\
\hline & Initial setting time [min] & 95 \\
\hline & Final setting time [min] & 420 \\
\hline \multirow{2}{*}{$\begin{array}{l}\text { 离 } \\
\text { 克 }\end{array}$} & Mortar compressive strength after 7 days $\left[\mathrm{N} / \mathrm{mm}^{2}\right]$ & 21.06 \\
\hline & Mortar compressive strength after 28 days [N/mm²] & 26.08 \\
\hline
\end{tabular}


The properties of fine aggregate, CS and coarse aggregate are given in Table 2 [15]. Specific gravity and density of CS amount to 3.52 and $1750 \mathrm{~kg} / \mathrm{m}^{3}$, respectively. These qualities show that the density of CS is in contrast to that of the fine aggregate. Similarly, CS has higher fineness modulus (3.68). It could be inferred from the results that the CS is coarser than the fine aggregate. Furthermore, gradation tests were conducted for fine aggregate, CS, and coarse aggregate. The gradation curves are presented in Figure 1. Potable water is generally considered for concreting purposes. Thus, locally available potable water was used for mixing and curing.

Table2. Properties of fine and coarse aggregate

\begin{tabular}{|c|c|c|c|}
\hline Property Agregate & $\begin{array}{l}\text { River } \\
\text { sand }\end{array}$ & $\begin{array}{l}\text { Copper } \\
\text { slag }\end{array}$ & $\begin{array}{c}\text { Coarse } \\
\text { aggregate }\end{array}$ \\
\hline Specific gravity & 2.5 & 3.52 & 2.7 \\
\hline Fineness modulus & 2.74 & 3.68 & 7.61 \\
\hline Bulk density $\left[\mathrm{kg} / \mathrm{m}^{3}\right]$ & 1420 & 1750 & 1380 \\
\hline Void ratio & 0.77 & 0.8 & 0.95 \\
\hline Grading zone & II & - & $\begin{array}{l}\text { Max. size } \\
20 \mathrm{~mm}\end{array}$ \\
\hline
\end{tabular}

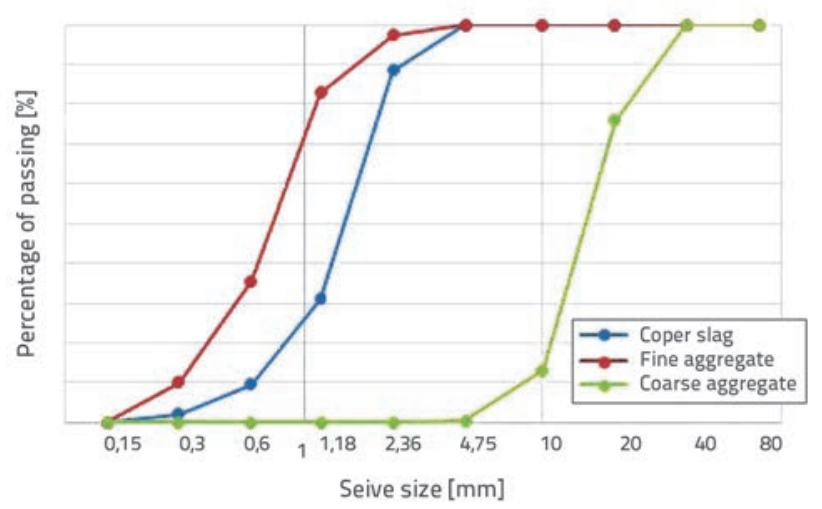

Figure 1. Particle size distribution for copper slag, fine aggregate and coarse aggregate

\subsection{Mix design proportions}

The concrete mixture is compliant with IS 10262-2009 [16] and its proportions are given in Table 3. C25/30 grade concrete was used in this research. In the designation of concrete mix, M30 was used, refers to the mix and the number to the specified compressive strength of $150 \mathrm{~mm}$ size cube at 28 days, expressed in $\mathrm{N} / \mathrm{mm}^{2}$. The cement and water cement ratio were kept constant as $380 \mathrm{~kg} / \mathrm{m}^{3}$ and 0.4 , respectively. Twenty four mix proportions were prepared. The cement was partially replaced by FA from $0 \%$ to $30 \%$ with $10 \%$ increments by mass, while fine aggregate was replaced by CS from $0 \%$ to $100 \%$, with $20 \%$ increments by volume.

\subsection{Preparation of test specimens}

The concrete was mixed in the laboratory tilting drum mixer machine. Concrete cubes $100 \mathrm{~mm}$ x $100 \mathrm{~mm}$ x $100 \mathrm{~mm}$ were cast so as to determine the saturated water absorption, porosity, coefficient of water absorption, and sorptivity. The samples were demoulded after $24 \mathrm{~h}$ and then cured under water up to 90 days. Standard cylindrical specimens $100 \mathrm{~mm}$ diameter and $50 \mathrm{~mm}$ length were cast for the chloride ion penetration test. These specimens were stripped after $24 \mathrm{~h}$ and cured with distilled water up to 90 days. Powdered samples for the alkalinity test were taken from specimens after 90 days of curing.

\section{Experimental tests}

The durability of concrete depends on environmental conditions and on the movement of water and gas entering and moving through concrete. Concrete containing supplementary cementitious materials such as FA required 56-90 days curing period in order to develop potential properties. The main objective of the present investigation was to study the microstructure related properties such as the Saturated Water Absorption (SWA), porosity, coefficient of absorption, sorptivity and chloride ion penetration, and $\mathrm{pH}$ values.

\subsection{Saturated water absorption (SWA)}

The SWA test was conducted in accordance with the ASTM C164213 [17]. After 90 days of curing period, the specimen was oven dried at $110{ }^{\circ} \mathrm{C}$ for no less than 24 hours, as shown in Figure 2.

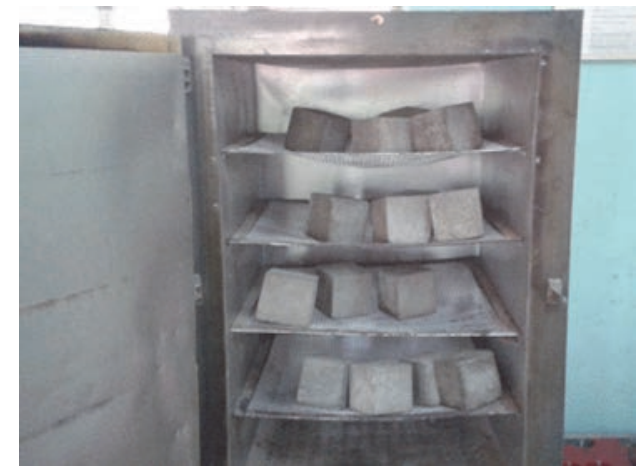

Figure 2. Concrete cubes in oven

Table 3. The composition of the concrete mixtures used in the test (designation M30)

\begin{tabular}{|c|c|c|c|c|c|}
\hline $\begin{array}{c}\text { Specified compression strength } \\
{\left[\mathrm{N} / \mathrm{mm}^{2}\right]}\end{array}$ & $\begin{array}{c}\text { Cement } \\
{\left[\mathrm{kg} / \mathrm{m}^{3}\right]}\end{array}$ & $\begin{array}{c}\text { Fine aggregate } \\
{\left[\mathrm{kg} / \mathrm{m}^{3}\right]}\end{array}$ & $\begin{array}{c}\text { Coarse aggregate } \\
{\left[\mathrm{kg} / \mathrm{m}^{3}\right]}\end{array}$ & $\begin{array}{c}\text { Water } \\
{\left[\mathrm{kg} / \mathrm{m}^{3}\right]}\end{array}$ & $\begin{array}{c}\text { w/c } \\
\text { ratio }\end{array}$ \\
\hline 30 & 380 & 596 & 1281 & 152 & 0.4 \\
\hline
\end{tabular}


After removal of each specimen from the oven, it was allowed to cool in dry air to determine the mass. When two consecutive mass values closely agreed, the specimen was considered dry. Then the concrete specimens were immersed in water until the constant mass was obtained. Soaking after immersion in [\%] is given by the expression (1):

$$
[(B-A) / A] \times 100[\%]
$$

where:

A - mass of oven dried sample in air, [g]

B - mass of surface dry sample in air after immersion, [g].

\subsection{Porosity}

Porosity is a measure of the proportion of pores in the total volume of concrete, and it is usually expressed in percentage. For the determination of porosity, the formula given with the expression (2) is used:

$$
[(\mathrm{A}-\mathrm{B}) / \mathrm{V}] \times 100 \quad[\%]
$$

where:

A - mass of oven dried sample in air, [g]

B - mass of surface dry sample in air after immersion, [g]

$\mathrm{V}$ - volume of sample.

The volume of voids is represented by the volume of water lost on oven drying at $105^{\circ} \mathrm{C}$ to constant mass.

\subsection{Sorptivity test}

The sorptivity was determined according to ASTM C1585-13 [18] at the age of 90 days. This test method is used to determine the rate of absorption (sorptivity) of water by measuring the increase in the mass of a specimen resulting from absorption of water as a function of time, when only one surface of the specimen is exposed to water. The exposed surface of the specimen is immersed in water and water ingress of unsaturated concrete is dominated by capillary suction during initial contact with water. The test determines the rate of capillary-rise absorption by a concrete $100 \mathrm{~mm}$ cube which rests on small supports in a manner such that only lowest 2 to $5 \mathrm{~mm}$ of the cube is submerged. It is shown in Figure 3.

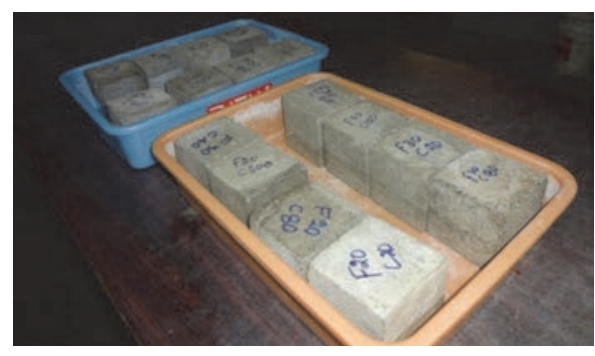

Figure 3. Sorptivity test

The increase in the mass of cube over time is recorded:
$\mathrm{i}=\mathrm{St}$

where:

i - increase in mass in $\mathrm{g} / \mathrm{mm}^{2}$ (mass increases due to the ingress of water, $1 \mathrm{~g}$ is equivalent to $1 \mathrm{~mm}^{3}$, so it can be expressed in $\mathrm{mm}$ )

$\mathrm{t}$ - time, measured in minutes, and at which the mass is determined

$\mathrm{S}$ - sorptivity in $\mathrm{mm} / \mathrm{min}^{0.5}$.

The quantity of water penetrated per unit surface area exposure to water is plotted against the square root of time of exposure. The test data generally fell on a straight line passing through the origin. The slope of this straight line is considered as a measure of the velocity of movement of water through capillary pores and is called sorptivity.

\subsection{Coefficient of absorption}

It is calculated from expression (4), according [19]:

$k a=(Q / A)^{2} \times(1 / t)$

where:

Q - quantity of water absorbed by the oven dried specimen over time $\mathrm{t}=60$ minutes

A - total surface area of concrete specimen affected by penetration of water.

Lower value of ka indicates higher degree of imperviousness of concrete for water penetration.

\subsection{Rapid chloride ion penetration test}

The chloride permeability is measured in accordance with ASTM C1202-12 [20] at the age of 90 days. This test method consists of monitoring the amount of electrical current passed through $50 \mathrm{~mm}$ thick and $100 \mathrm{~mm}$ nominal diameter disc during a 6 -hour period. A potential difference of $60 \mathrm{~V}$ direct current is maintained across the end of the specimen. One side of the cell is immersed in a $3 \%(\mathrm{NaCl})$ sodium chloride solution and is connected with the negative terminal of power supply. The other side of the cell is filled with 0.3N $(\mathrm{NaOH})$ sodium hydroxide solution and connected with positive terminal of the power supply. It is depicted in Figure 4.

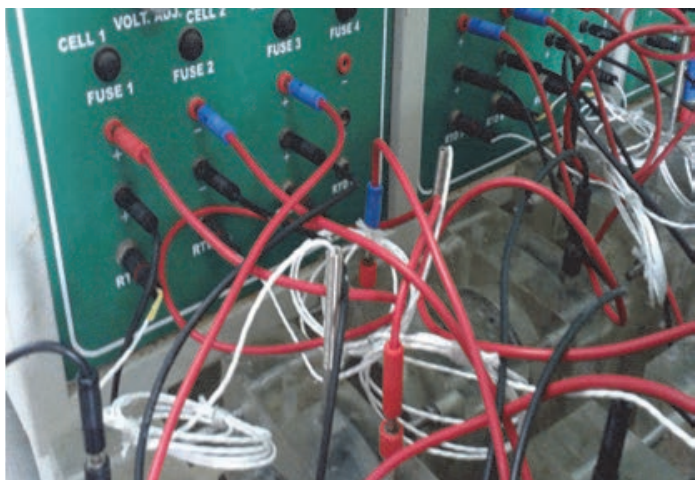

Figure 4. Rapid chloride ion penetration test 
Table 4. Results of durability properties and alkalinity test

\begin{tabular}{|c|c|c|c|c|c|c|c|}
\hline \multicolumn{2}{|c|}{$\begin{array}{c}\text { Combination of Fly Ash (FA) } \\
\text { and Copper Slag (CS) } \\
\text { in concrete }\end{array}$} & \multirow{2}{*}{$\begin{array}{c}\begin{array}{c}\text { Saturated water } \\
\text { absorption }\end{array} \\
4.1\end{array}$} & \multirow{2}{*}{$\begin{array}{c}\begin{array}{c}\text { Porosity } \\
{[\%]}\end{array} \\
11\end{array}$} & \multirow{2}{*}{$\left.\begin{array}{c}\begin{array}{c}\text { Coefficient of } \\
\text { absorption }\end{array} \\
\text { In } \times 10^{-14}[\mathrm{~mm} / \mathrm{s}]\end{array}\right]$} & \multirow{2}{*}{$\begin{array}{c}\begin{array}{c}\text { Sorptivity } \\
\times 10^{-4}\end{array} \\
{\left[\mathrm{~mm} / \mathrm{min}^{-0.5}\right]}\end{array}$} & \multirow{2}{*}{$\begin{array}{c}\text { Rapid chloride } \\
\text { penetration test } \\
{[\mathrm{C}]}\end{array}$} & \multirow{2}{*}{$\begin{array}{c}\text { pH value } \\
12.5\end{array}$} \\
\hline FAO & CS50 & & & & & & \\
\hline FAO & CS2O & 3.6 & 9 & 0.42 & 1 & 300.7 & 11 \\
\hline FAO & CS40 & 3.8 & 10 & 1.15 & 2 & 200.5 & 11.3 \\
\hline FAO & CS60 & 3.5 & 8.5 & 1.67 & 1 & 580 & 11.3 \\
\hline FAO & CS80 & 3.3 & 8 & 2.26 & 1 & 197.1 & 11.5 \\
\hline FAO & CS100 & 3 & 8 & 0.74 & 0.6 & 249.3 & 11.6 \\
\hline FA10 & CS50 & 4.2 & 11 & 0.42 & 1 & 200.7 & 11 \\
\hline FA10 & CS2O & 3.9 & 10 & 0.42 & 1 & 378.9 & 11.1 \\
\hline FA10 & CS40 & 4.2 & 11 & 0.74 & 2 & 200.7 & 11.1 \\
\hline FA10 & CS60 & 3.7 & 10 & 0.74 & 1 & 801.9 & 11.1 \\
\hline FA10 & CS80 & 3.2 & 9 & 0.42 & 1 & 102.6 & 11.1 \\
\hline FA10 & CS100 & 2.4 & 7 & 0.42 & 1 & 194.4 & 11.1 \\
\hline FA20 & CS50 & 4 & 10 & 0.74 & 1 & 264.6 & 10.5 \\
\hline FA20 & CS20 & 3.6 & 9 & 0.74 & 2 & 128.7 & 10.6 \\
\hline FA20 & CS40 & 3.8 & 10 & 0.42 & 2 & 261.9 & 10.5 \\
\hline FA20 & CS60 & 3.3 & 9 & 0.18 & 1 & 587.7 & 10.5 \\
\hline FA20 & CS80 & 3.2 & 9 & 0.42 & 1 & 283.5 & 10.7 \\
\hline FA20 & CS100 & 2.8 & 8 & 0.42 & 1 & 195.3 & 10.8 \\
\hline FA30 & CS50 & 4.6 & 11 & 0.42 & 1 & 267.3 & 10.2 \\
\hline FA30 & CS2O & 4.2 & 11 & 0.74 & 2 & 184.5 & 10.8 \\
\hline FA30 & CS40 & 5.6 & 14 & 0.74 & 2 & 151.2 & 10.9 \\
\hline FA30 & CS60 & 4.2 & 12 & 0.42 & 2 & 302.4 & 11 \\
\hline FA30 & CS80 & 3.2 & 9 & 0.42 & 1 & 101.7 & 11.7 \\
\hline FA30 & CS100 & 3.2 & 9 & 0.42 & 1 & 249.3 & 10.5 \\
\hline
\end{tabular}

The total charge passed, in coulombs, was found to be related to the resistance of the specimen to chloride ion penetration.

$Q=900\left(I_{0}+2 I_{30}+2 I_{60}+\ldots \ldots . .2 I_{300}+2 I_{330}+I_{360}\right)$

where:

Q - charge passed (coulombs)

$\mathrm{I}_{0}$ - current (amperes) immediately after voltage is applied

$I_{t}$ - current (amperes) at $t$ min after voltage is applied

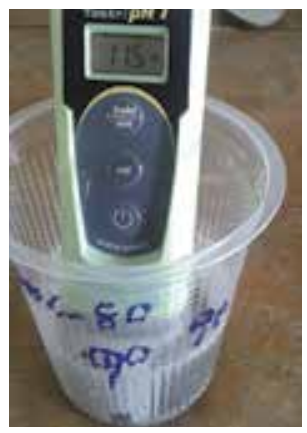

Figure 5. Alkalinity test

\subsection{Alkalinity test}

Ten gram crushed samples were taken from twenty-four mix proportions at the age of 90 days and mixed with 50 $\mathrm{ml}$ distilled water. The mixture was completely stirred. The solution was kept for 72 hours and then $\mathrm{pH}$ meter was immersed into the solution. The structure is shown in Figure 5. The $\mathrm{pH}$ values of the solution are presented in Table 4.

\section{Results and discussion}

After 90 days of water curing, specimens were tested to determine durability properties such as the SWA, porosity, coefficient of absorption, sorptivity and chloride ion penetration by Rapid Chloride Penetration Test (RCPT). The Alkalinity $(\mathrm{pH})$ test was also conducted. The results are given in Table 4.

\section{Saturated water absorption, Porosity and Coefficient of water absorption}

The SWA and porosity values are presented in Figure 6 . These values are higher, when concrete does not contain CS. Therefore, the filling effect of concrete is reduced if CS is not added and, hence, the pore diameter of the cement paste is increased. The SWA and porosity values increase when concrete with $40 \%$ of CS is replaced by sand. Furthermore, the values decrease continuously when $100 \%$ sand replacement with CS is reached. When natural sand is replaced by $100 \%$ of CS, the SWA values amount to $3 \%, 2.4 \%, 2.8 \%$ and $3.2 \%$ for $0 \%, 10 \%, 20 \%$, and $30 \%$ of FA, respectively. The values show 
that they are by $27 \%, 41 \%, 32 \%$ and $22 \%$ smaller compared to the control concrete. Moreover, average concrete porosity values are $8 \%, 7 \%, 8 \%$, and $9 \%$ for $0 \%, 10 \%, 20 \%$ and $30 \%$ of FA, respectively. When compared to the control concrete, these values are lower by $27 \%, 36 \%, 36 \%$ and 18 $\%$, respectively. Generally, the SWA and porosity decrease when sand is replaced by $80 \%$ and $100 \%$ of CS and cement is replaced by $0-30 \%$ of FA. These experimental results show that the concrete water absorption rate increases linearly with the porosity of concrete.

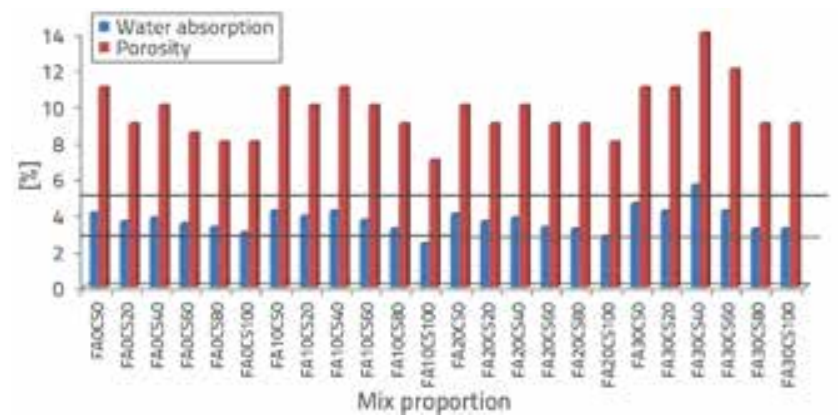

Figure 6. Water absorption and porosity

According to [7], if the value of SWA is below $3 \%$, it is considered to be a "good" concrete. If the SWA ranges from $3 \%$ to $5 \%$ it is considered as an "average" concrete and, above $5 \%$, it is classified as a "poor" concrete. In this paper, the values of SWA are 2.4 $\%$ and $2.8 \%$ for FA10CS80 and FA20CS80, respectively. Hence, this concrete may be considered as a good concrete. All other mix proportions except FA30CS40 are classified as average. This shows an insufficiency of gel pores due to hydration, and so capillary pores are interconnected. Even complete hydration would not produce enough gel to block all the capillaries. The higher SWA represents more pores and greater movement of water and, hence, a higher degree of volume changes.

A regression analysis (curve fitting techniques) was conducted in order to estimate the effect of the CS and FA on the SWA and porosity. A good correlation between the SWA and porosity was established, as shown in Figure 7. The exponential equation is well fitted with experimental data. The correlation index or the coefficient of determination $\left(R^{2}\right)$ varies from 0.76 to 0.93 . It expresses the proportion of variance in the dependent variable like porosity explained by an independent variable such as water

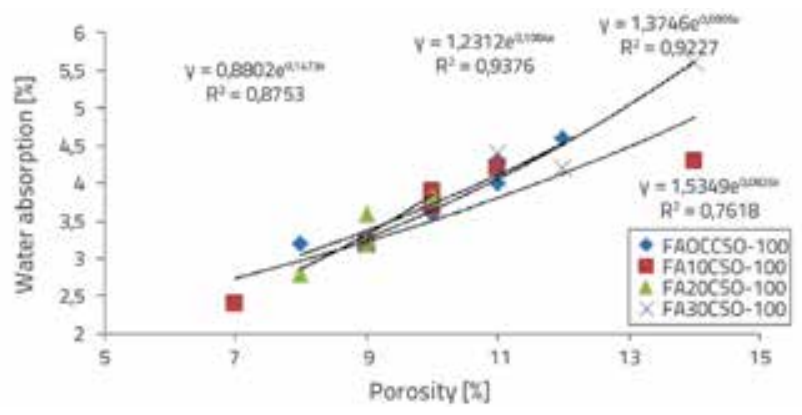

Figure 7. Variation of SWA with porosity absorption. It can therefore be stated that an economical and low absorption concrete depends on the selection of appropriate quantities of cement, FA and CS.

The coefficient of water absorption of concrete falls from 0.18 $\times 10^{-14} \mathrm{~mm} / \mathrm{s}$ to $2.26 \times 10^{-14} \mathrm{~mm} / \mathrm{s}$ when cement is replaced by $0 \% \mathrm{FA}$ and sand is replaced by $80 \%$ of CS, the highest value being $2.26 \times 10^{-14} \mathrm{~mm} / \mathrm{s}$. This is by $96 \%$ higher compared to the control concrete, whereas the coefficient of water absorption is less for concrete with the CS and FA combination. The above combination ensures a good particle packing density. Moreover, a hydration product such as the surplus $\mathrm{Ca}(\mathrm{OH})_{2}$ is consumed by FA and gives an additional $\mathrm{C}-\mathrm{S}-\mathrm{H}$ gel to the concrete. So, the solid content of the paste increases with an increase in the duration of hydration and, hence, the dense paste is created in the mature state. The capillaries are blocked by gel and segmented. Hence, they turn into capillary pores and are filled by gel pores. Consequently, the capillary pores are disconnected and, as a result, penetration of water through pores is reduced. On the other hand, capillary pores decrease with the progress of hydration.

\section{Sorptivity}

Sorptivity is the rate of unidirectional movement of water through capillary suction. For all mix proportions, sorptivity values range from $0.6 \times 10^{-4}$ to $2 \times 10^{-4} \mathrm{~mm} /(\mathrm{min})^{0.5}$. Lower values are preferable. These values indicate that water penetrates at a very slow rate. In addition, it can be seen from the results that FAOCS100 concrete exhibits greater resistance to water absorption by capillary suction than the concrete containing FA and CS. Typical plots of cumulative water absorption against the square root of time are shown in Figure 8 for all the twenty-four concrete mix proportions tested.
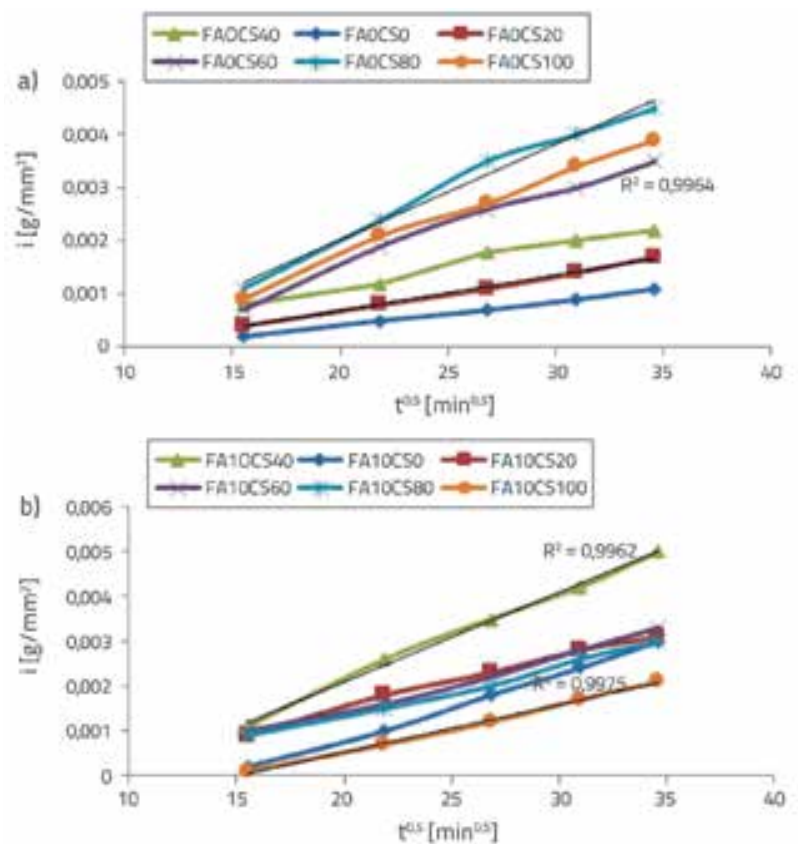

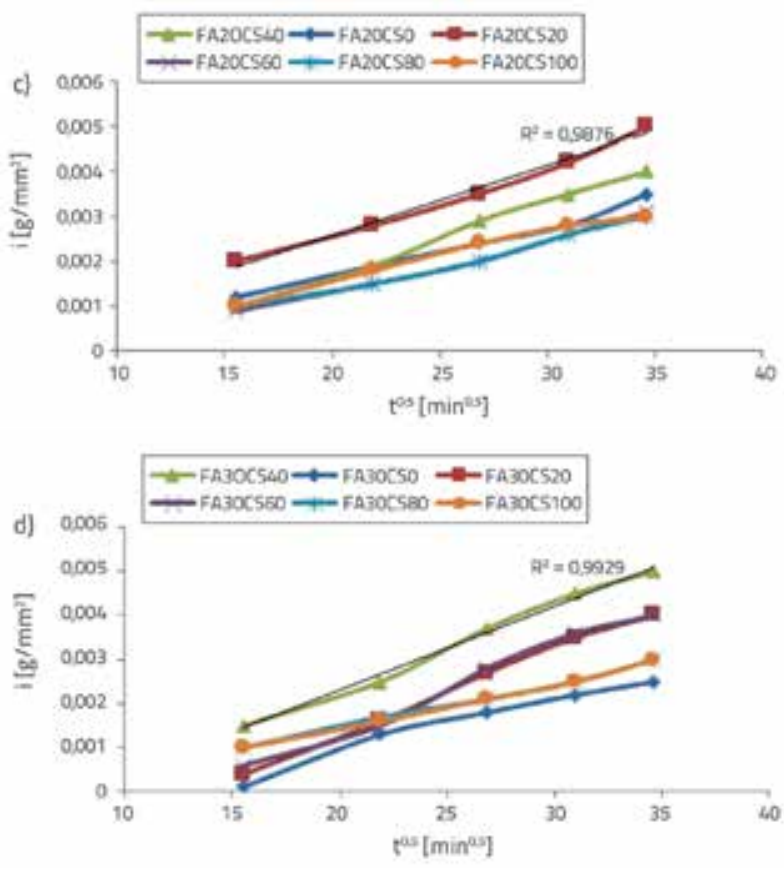

Figure 8. Cumulative water absorption for concrete containing FA and CS

This duration has produced linear relationships (least squares fitting) which give correlation index of the coefficient of determination $\left(\mathrm{R}^{2}\right)$ greater than 0.99. Water absorption of a concrete surface depends on many factors including concrete mix proportions, supplementary cementitious materials, duration of curing, and degree of hydration or age.

\section{Chloride penetration}

This test is conducted for all mix proportions for the time of up to six hours. The results are presented in Figure 9. These results are compared with ASTM [1202] [20].

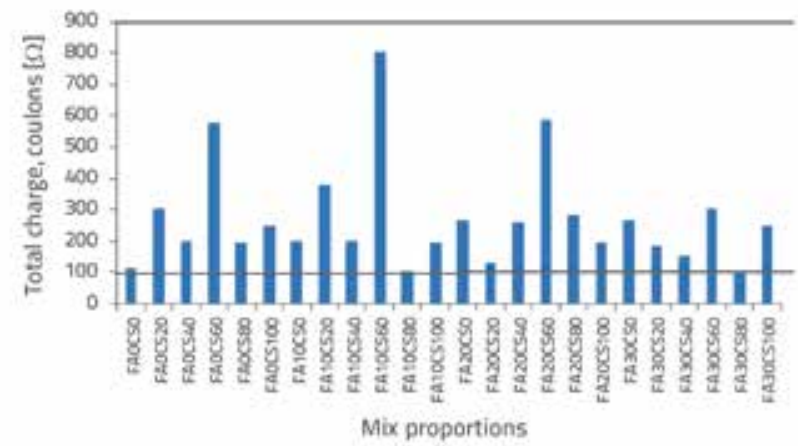

Figure 9. Chloride permeability values for concrete

As per the ASTM [1202-12], the chloride ion penetrability is based on the total charge passed on the concrete in "coulombs". If the charge passed is < 100 coulombs, the chloride ion penetrability is "negligible". The charge passed varying between
100 and 1000 coulombs is described as "very low", and the charge passed ranging from 1000 to 2000 coulombs is characterised as "low". The charge passed varying from 2000 to 4000 coulombs is considered as "moderate", and the charge passed of > 4000 coulombs is designated as "high". It could be inferred from the results that the chloride ion penetrations have less than 1000 coulombs for all concrete mixes. Total charges passed for $10 \%$ and $30 \%$ replacement of FA have very low values such as 102.6 coulombs and 101.7 coulombs, respectively, for $80 \%$ fine aggregate replacement by CS. It can be concluded from these results that the combination of these two industrial waste materials performs well, and also that it reduces porosity in concrete. Thus the penetration of chloride ion is reduced and, hence, corrosion is prevented. FA is added as replacement for cement. It reacts with $\mathrm{Ca}(\mathrm{OH})_{2}$ in the hydrated cement paste and forms complex compounds that reduce the permeability and improve the durability besides improving the economy of the mix.

\section{Alkalinity}

$\mathrm{pH}$ values of all mix proportions are shown in Figure 10. The $\mathrm{pH}$ values range from 10.2 to 12.5 . It can be seen from the results that the $\mathrm{pH}$ value of all mix proportions decreases due to higher consumption of free lime $\left(\mathrm{Ca}(\mathrm{OH})_{2}\right)$ in concrete. The only advantage is that $\mathrm{Ca}(\mathrm{OH})_{2}$, being alkaline in nature, maintains the $\mathrm{pH}$ value at around 13 in concrete, which prevents corrosion of reinforcement. However, the surplus calcium hydroxide reacts with sulphates present in the soil or water to form calcium sulphate, which further reacts with $C_{3} A$ and causes deterioration of concrete. The use of blending materials such as fly ash, silica fume and other such pozzolanic materials is recommended so as to reduce the quantity of $\mathrm{Ca}(\mathrm{OH})_{2}$ in concrete, and to overcome its bad effects by converting it into a cementitious product [4]. The $\mathrm{pH}$ value of pozzolanic concrete is much lower than that of ordinary concrete due to absence of free lime in concrete mix, which is not favourable for corrosion resistance of concrete reinforcement [21].

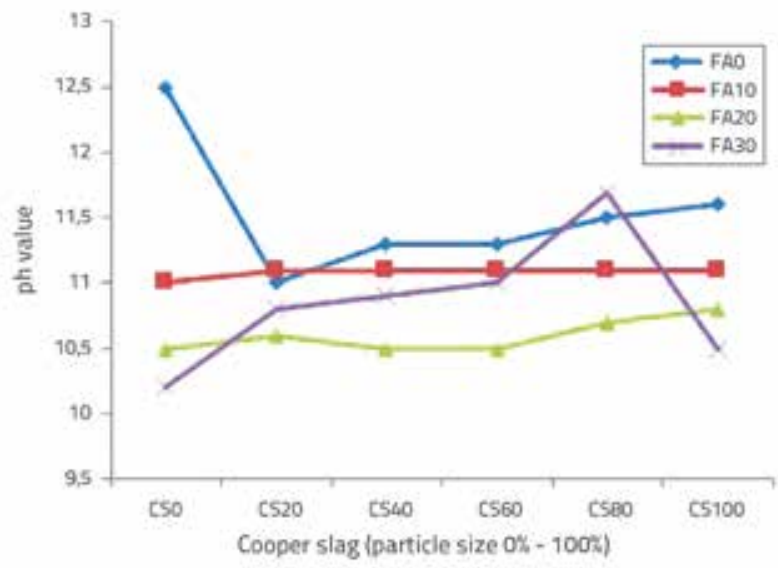

Figure 10. pH values for concrete containing FA and CS 

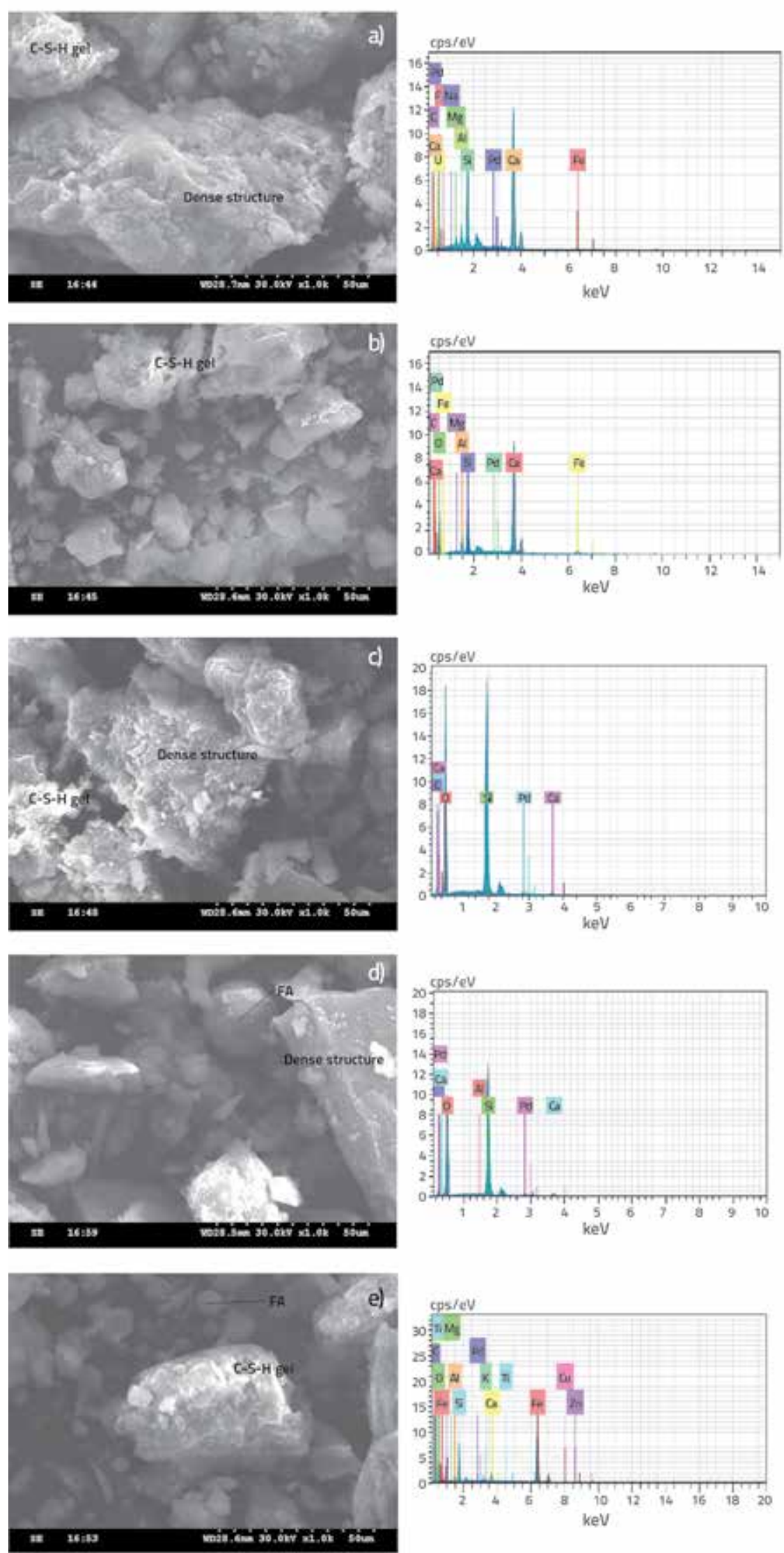

Figure 11. SEM and EDAX images for: a) FAOCSO; b) FAOCS80; c) FA10CS80; d) FA20CS80; e) FA30CS80

\section{Microstructure of concrete}

The microstructure study was conducted to observe the structure of concrete containing CS and FA. The Scanning Electron Microscopy (SEM) was used to record micrographs whereas the Energy dispersive X-ray spectroscopy (EDAX) was used for quantitative analysis. The results obtained by the EDAX analysis are presented as the atomic percentage of each element. Based on experimental results, concrete with $80 \%$ and $100 \%$ of CS substituted for fine aggregate behave better compared to other concretes. Thus the SEM and EDAX analyses were conducted for control concrete, minimum water absorption and porosity of samples at 90 days. The SEM image and typical EDAX spectra for elemental analysis of FAOCSO, FAOCS80, FA10CS80, FA20CS80 and FA30CS80 are given in Figure 11. It can be seen from these results that major components found in all specimens are $\mathrm{Si}, \mathrm{Ca}$, and $\mathrm{Al}$. Other elements such as $\mathrm{Na}, \mathrm{Mg}, \mathrm{Ti}, \mathrm{Fe}$, and $\mathrm{Pd}$ are found in much smaller quantities. There were no great differences in the microstructure of all concrete mixes and, also, a major hydration product was found in all samples. In Figure 11.a for control concrete (FAOCSO), the hydrated cement paste is in the form of dense structure only. The EDAX analysis shows Si (36.02 $\%$ ) as the only main element of this component.

In Figure 11.b and 11.c for FAOCS80 and FA10CS80, there are no unreacted fly ash particles, needle shaped ettringite and surplus $\mathrm{Ca}(\mathrm{OH})_{2}$. It can be seen from these results that $\mathrm{Ca}$ $(\mathrm{OH})_{2}$ converts into secondary C-S-H gel by pozzolanic reaction and forms a continuous binding matrix. It is amorphous and fibrous and, hence, it has a large surface area resulting in generation of a discontinuous pore structure. Thus the microstructure changes greatly with incorporation of fly ash and CS. In Figure 11.d and 11.e for FA20CS80 and FA30CS80, there are a few un-hydrated FA and hydration products. It can be seen that most of the FA is consumed by the surplus lime 
and that the unreacted FA acts as micro-filler. Hence, concrete becomes denser and durability increases. Generally, there is no needle shaped ettringite and plate shaped $\mathrm{Ca}(\mathrm{OH})_{2}$ in all images. It could be inferred from this that the permeability of concrete reduces with the use of pozzolanic materials in an optimum proportion. The pore refinement process occurs due to conversion of calcium hydroxide into secondary $\mathrm{C}-\mathrm{S}-\mathrm{H}$ gel by pozzolanic action.

\section{Conclusion}

The following conclusions can be drawn from this experimental investigation:

- Based on SWA and porosity tests, concrete with $100 \%$ CS replacement for fine aggregate and $10 \%$ and $20 \%$ cement replacement by $\mathrm{FA}$, is suitable for use in any severe environmental conditions. At the same time, concrete with $30 \% \mathrm{FA}$ and $40 \%$ CS replacement for sand is considered as a poor concrete because of higher SWA (>5\%).

- Initially water absorption coefficient values are higher without FA and when fine aggregate is replaced by $80 \%$ of CS. Finally, based on SWA, this mix proportion is considered good and the concrete structure is also capable of withstanding harmful effects in water prone areas.

- The unidirectional flow of water (sorptivity) of concrete with FA30 \% and $100 \%$ replacement for CS is similar to the control concrete. This mixture may be used as an economical mix.

- The RCPT test shows that, according to ASTM [C1202-12], the chloride ion penetration is very low and this mixture is suitable for seashore areas.

- pH values of all mix proportions vary from 10.5 to 11.7, except for the control concrete. This is not favourable for corrosion resistance of concrete because of higher consumption of surplus lime in concrete.

- The SEM and EDAX images show that durability properties of concrete improve when the combination of FA and CS is used. Only a few un-hydrated FA particles are present. This signifies that FA is consumed by the $\mathrm{Ca}(\mathrm{OH})_{2}$ and gives additional C-S-H gel to the concrete. Hence, pore structure is reduced and dense structure is formed.

- Durability property tests carried out in this work prove the durability of the combination of CS and FA and that this concrete structure is cost effective.

- Acknowledgement

The authors wish to thank Alagappa Chettiar College of Engineering and Technology, Karaikudi, Sterlite Industries (India) Ltd., Tuticorin, India, and Thermal power plant Salem, India, for providing all facilities for carrying out this work.

\section{Acknowledgments}

The authors thank the Alagappa Chettiar Faculty of Engineering, Sterlite Industries d.o.o (India), Tuticorin (India) and Thermoelectric Power Plant Salem (India) for the resources they have provided in connection with this paper.

\section{REFERENCES}

[1] Neville, A.: Properties of concrete, $4^{\text {th }}$ edition, Longman, London, 1995.

[2] Gambhir, M.L.: Concrete technology-Theory and practice, 4th edition, Tata Mcgraw hill education, Newdelhi, 2009.

[3] Santhakumar, A.R.: Concrete technology, Ninth impression,Oxford, Newdelhi, 2012.

[4] Shetty, M.S.: Concrete technology-Theory and practice, S. Chand, Pune, 1982.

[5] Sososro, M.: Transport of organic fluids through concrete, Materials and structures, 31 (1998), pp 162-169, https://doi. org/10.1007/BF02480390

[6] Hall, C.: Water sorptivity of mortars and concretes- a review, Magazine of concrete research, 41 (1989) 147, pp. 51-61, https:// doi.org/10.1680/macr.1989.41.147.51

[7] Amarnath, Y., Ganeshbabu, K.: Transport properties of high volume fly ash roller compacted concretre, Cement and Concrete composites, 33 (2011), pp. 1057-1062, https://doi.org/10.1016/j. cemconcomp.2011.07.010

[8] Nath, P., Sarker, P.: Effect of Fly ash on the durability properties of high strength concrete, The twelfth East Asia-pacific conference on structural engineering and construction, Procedia Engineering, 14 (2011), pp. 1149-1156, https://doi.org/10.1016/j. proeng.2011.07.144
[9] Sabir, B.B., Wild, S., Farrel, M.O.: A water sorptivity for mortar and concrete, Materials and Structutres, 31 (1998), pp 568-574, https://doi.org/10.1007/BF02481540

[10] Wu, W., Zhang, W., Ma, G.: Optimum content of copper slag as fine aggregate in high strength concrete, Materials and design, 31 (2010), pp. 2878-2883, https://doi.org/10.1016/j. matdes.2009.12.037

[11] Khalifa, J., Al, S., Hisada, M., Salem, K., Al, O.A., Al-Saidy, H.: Copper slag as sand replacement for high performance concrete, Cement and concrete composites, 31 (2009), pp. 483-488, https://doi. org/10.1016/j.cemconcomp.2009.04.007

[12] Palani, T. Jaya, K.P., Muthumani, K.: Studies on copper slag substitution for sand in high strength concrete, Journal of structural engineering, 41 (2014) 4, pp.293-306.

[13] IS8112 (part1):2013 Ordinary Portland Cement 43 grade, Bureau of Indian Standards, New Delhi.

[14] IS3812 (part1):2003 Pulverized Fuel Ash-Specification part1 for use as pozzalana in cement, cement mortar and concrete, Bureau of Indian Standards, New Delhi.

[15] IS383-1970 Specification for Coarse and Fine Aggregates from natural sources for Concrete. Bureau of Indian Standards, New Delhi.

[16] IS10262-2009 Concrete Mix Proportioning-Guidelines, Bureau of Indian Standards, New Delhi. 
[17] ASTM C642-13 Standard test method for Density, Absorption, and voids in Hardened concrete.

[18] ASTM C1585-13 Standard test method for Measurement of rate of Absoption of water by hydraulic cement concretes.

[19] Peter, J.A., Neelamegam, M., Dattatreya, J.K., Rajamane, N.P., Gopalakrishnan, S.: Utilization of Fly ash as cement replacement material to produce high performance concrete, SERC, CSIR Campus, Taramani. Chennai, Fly ash utilization for value added product, pp 38-49.
[20] ASTM C1202-12 Standard Test method for- Electrical indication of concrete's ability to resist chloride ion penetration.

[21] Varghese, P.C.: Limit sate design of reinforced concrete, second edition, PHI learning Private limited, Delhi 2013. 